\title{
Doing Business and Increasing Emissions? An Exploratory Analysis of the Impact of Business Regulation on $\mathrm{CO}_{2}$ Emissions
}

\author{
Annika Rieger \\ Department of Sociology, Boston College \\ Massachusetts, United States
}

\section{Abstract}

Since 2005, the World Bank has released a data set titled Doing Business: Measuring Business Regulations. These data have become an important set of indicators of international business climate. However, the impacts of pro-business regulation on the environment have generally been overlooked. To help resolve this problem, I estimate a time-series cross-sectional Prais-Winsten regression model to test the relationship between business climate-represented by the World Bank's Doing Business data set-and carbon dioxide $\left(\mathrm{CO}_{2}\right)$ emissions in developing nations over 10 years, from 2005 to 2014 . The results show that there is a statistically significant and positive association between business climate and $\mathrm{CO}_{2}$ emissions in developing nations. This shows that pro-business regulations contribute to increasing $\mathrm{CO}_{2}$ emissions in developing nations, a major driver of global climate change. I suggest that these results are due to business climate encouraging environmental load displacement, which posits that developed nations are partially displacing their environmental impacts onto developing nations.

Keywords: business climate, climate change, environmental load displacement, environmental sociology, political economy

\section{Introduction}

Business climate is a term widely employed to denote the economic environment in which businesses operate, predicted by various conditions relevant to the conduct of business, prevailing within a nation, a region, or globally. Business climate is most commonly associated with regulatory or policy conditions, but includes other conditions such as business relationships with labor unions, political attitudes, and

1 Corresponding author: annika.rieger@bc.edu. 
economic stability. While "business climate" is a popular buzzword, the effects of the application of its principles by the World Bank, governments, and corporations has been under-studied in the social sciences, especially in terms of its environmental impacts. This is surprising, considering how closely tied the concept is to business growth and economic development, as well as the abundance of research detailing how economic growth is a primary human driver of climate change. Despite these connections, the relationship between business climate and the environment is unclear. While some regulations are passed to protect the environment and limit environmentally damaging business practices, others could also make it easier to start and expand businesses by simplifying complex processes. The potential environmental impacts of business climate are important to consider, especially since the creation of a "good business climate" is gaining notice due to the concept's promotion by the World Bank as something that developing nations should prioritize for economic development. The World Bank has encouraged governments to adopt pro-business policies to stimulate economic growth, and this implementation has led to business-friendly practices being codified into law.

In this study, I examine the association between pro-business climate and anthropogenic carbon dioxide $\left(\mathrm{CO}_{2}\right)$ emissions, as well as exploring some possible explanations about the nature of this association. I suggest that "good business climate" is one way to facilitate the displacement of the developed world's environmental harms - which stem from production and material consumptiononto the developing world, where the materials for production are extracted, and now increasingly the goods for consumption themselves are produced.

Global governance institutions, such as the World Bank, are changing the way they disseminate normative models of development: no longer through conditions attached to loans, but diffused through economic policy (Babb, 2009; Kentikelenis et al., 2016). Encouraging a pro-business climate is one way to frame the opening-up of countries to international economic markets in the name of economic development. While developing nations who make an effort to create such a business climate are often rewarded with an influx of industry and foreign direct investment, these industries and investments are often those with the most detrimental environmental effects (Jorgenson et al., 2007). Building on the academic literature, I have two broad research questions: given the ways in which regulation has been tied to business interests, what is the relationship between $\mathrm{CO}_{2}$ emissions and business climate? And how much does an international regulatory environment that is "good for business" influence $\mathrm{CO}_{2}$ emissions?

To examine these questions, I use the World Bank's Doing Business data setspecifically the "Distance to Frontier" measure-which assigns nations a score out of 100 on 10 regulatory attributes that together create a so-called good business climate. I use this score to examine the impact of business climate on $\mathrm{CO}_{2}$ in developing nations that are classified as middle-income and low-income. I find 
that the Distance to Frontier scores are positively associated with $\mathrm{CO}_{2}$ emissions in the sample of developing nations. This relationship holds, even when controlling for variables such as foreign direct investment and GDP, both of which have been previously established as factors associated with environmental load displacement in general, and growth in carbon emissions in particular. One possible explanation is that the creation of a good business climate is a pathway through which environmental load displacement is occurring; that is, high-income nations are offshoring carbonintensive industries to those developing nations that are more pro-business.

\section{Literature review}

A well-established and growing body of social science literature focuses on the human drivers of climate change (for recent overviews, see Jorgenson et al., 2015; Rosa et al., 2015). In particular, scholars have linked certain types of economic policies, such as deregulation and neoliberalism, to environmental degradation because they contribute to the cycles of resource extraction, production, and consumption (Rudel et al., 2011). Higher levels of economic inequality and unequal distribution of economic power within nations are associated with higher levels of pollution and environmental degradation (Jorgenson et al., 2015). Within this system of inequality, the globalized economy has externalized costs to developing nations, allowing for artificially low prices on consumer goods and material resources in developed nations (Schor, 2005). Developing nations are also under the purview of global institutions such as the World Bank, which have fashioned development into a "project," aiming to integrate all countries into the world economy (McMichael, 2012).

Within this context, business climate is often codified into economic policies (Steinnes, 1984) with the purpose of promoting economic growth (Djankov et al., 2006; Neumark \& Muz, 2016). Business climate has also become a matter of interest for the World Bank as a global development institution: it produces annually a measure of business regulatory climate titled Doing Business ${ }^{2}$ (2017b). This combination of factors suggests that business climate has the potential to act as a pathway for environmental load displacement.

\section{International business climate}

In exploring the relationship between businesses, regulation, and the environment, it is essential to distinguish between two different types of regulation: environmental and pro-business policy. Past scholarly research has focused on how explicitly environmental regulation has had impacts on business; either by encouraging innovation, stifling growth, or something in between (for an overview see Ambec

2 This dataset, created in 2005 and published annually, uses 10 subscales, each measuring a different area integral to the creation of a "good business climate," in order to rank 186 nations from best to worst (World Bank 2017b). 
et al., 2013). Companies often focus on the costs associated with regulation and make efforts to avoid it. However, some companies view a lack of engagement with environmental concerns as a risk and have instead used climate change or other sustainability concerns as a business opportunity (Tsalis \& Nikolaou, 2017).

Environmental protection could arise endogenously from within the business community due to external, non-governmental pressures, which could be adopted into a global business climate. For instance, a study of the effects of globalization on environmental self-regulation in China shows that multinational firms are more likely than domestic firms to self-regulate by adhering to international standards; though this is partially due to the higher regulatory standards in the developed nations where the multinational firms are usually based (Christmann \& Taylor, 2001). Markets within a nation or region that are early adopters of innovations, often in the form of technology or practice, are known as "lead markets." These markets have the potential to act as an avenue for environmental protections when the new technologies or practices adopted are eco-friendly and sustainable: examples include companies that transition to wind energy use or produce eco-friendly technologies such as fuel-efficient vehicles (Beise \& Rennings, 2005). However, the diffusion of environmental protections through lead markets often depends on government interventions and regulations to protect the markets themselves (Beise $\&$ Rennings, 2005). These aspects of business climate have the potential to help protect rather than harm the environment.

Indicators of good business climate are often focused on low tax rates and reduced business costs, with the expectation that an influx of businesses drawn by favorable indicators will lead to economic growth (Steinnes, 1984; Neumark \& Muz, 2016). However, a study in the United States indicates that business climate measures focused on low costs and taxes are positively associated with inequality (Neumark $\&$ Muz, 2016). This suggests that, despite the potential for economic growth, pro-business climate can have unintended, negative consequences for social and ecological sustainability.

\section{The role of the World Bank}

As a development agency, the World Bank has the ability to influence global norms: environmental policy reforms are often diffused from global institutions who exert top-down pressure on nations to adopt legislation (Longhofer et al., 2016). Traditionally, the World Bank has used its ability to limit access to promised resources, in the form of loans, to force countries to adopt specified policies (Babb \& Chorev, 2016). However, the use of conditionalities has been critiqued, causing international financial institutions to find new methods of encouraging the adoption of such policies (Kentikelenis et al., 2016). 
The creation of the Doing Business data set is one such way to create knowledge that is viewed as credible by policy-makers, and then used to inform policy decisions (Broome et al., 2017). Through the Doing Business data set, the World Bank is attempting to measure a part of the policy climate that is theorized to be essential for economic progress: business regulation (Besley, 2015). This provides incentives for countries to establish policies that align with the specified practices and accept the resulting data sets, such as Doing Business, as measures of their success. Furthermore, the World Bank has published studies which boast that the economies of those countries with "better" business regulations (as defined in the Doing Business data set) have faster economic growth (Djankov et al., 2006). The connections made between business climate and economic growth suggest possible mechanisms by which business climate could impact the environment.

\section{Environmental load displacement}

The ecological unequal exchange perspective emphasizes that inequality among nations engaging in the global economy results in the offshoring of environmental damages from wealthier to poorer countries (Bunker, 1984; Hornborg, 2009). The impacts of industrialization are not spread evenly across developed and developing nations relative to their use of resources (Jorgenson, 2004). Wealthier nations are able to outsource the environmental impacts of their consumption levels to poorer nations, where the extraction of resources for and minor production of consumer goods takes place (Jorgenson, 2006). Wealthier nations are also offshoring hazardous waste from domestic industries, as well as the hazardous industries themselves (Frey, 1994). Environmental load displacement is a core concept within ecologically unequal exchange theory. It describes a process by which pollution and other human-driven forms of environmental degradation are outsourced from developed nations to less developed nations (Jorgenson, 2016). There are multiple pathways through which environmental load displacement can occur: the literature addressing ecological unequal exchange has primarily focused on foreign direct investment and trade networks as facilitators of this sort of outsourcing of environmental harms (e.g., Grimes \& Kentor, 2003; Muradian et al., 2002; Jorgenson, 2006; Rice, 2007; Hornborg, 2009; Bonds \& Downey, 2012; Huang, 2018).

Even green initiatives, such as environmentally beneficial technologies, can act as a pathway through which environmental load displacement occurs: the resources needed to produce these technologies involve destructive extraction practices, subsidizing the lifestyles of the developed world with environmental degradation in the developing world (Bonds \& Downey, 2012). However, nations pursuing the improvement of their business climate often end up experiencing environmental degradation with limited evidence to show that any economic development has occurred as a result of improved business climate. The studies that show that there is a positive relationship between business climate and economic growth often come from the creators of the Doing Business data set themselves (e.g., Djankov et al., 2006). 
However, given that environmental load displacement not only paints a false picture of "sustainability" in developed nations but also adds to the many issues facing developing nations as they try to improve quality of life (Muradian et al., 2002; Muradian \& Martinez-Alier, 2001), it is important to consider additional ways in which the displacement of carbon emissions and other forms of pollution and degradation are occurring. Business climate has been discussed within the literature on ecological unequal exchange as a facilitator of foreign direct investment, which has a positive association with carbon emissions and deforestation (Shandra, 2007; Jorgenson, 2007, 2009). Foreign direct investment channeled into manufacturing sectors in developing nations has resulted in inefficient production due to older machinery and lack of protective regulations, leading to higher levels of pollution, and contributes to the outsourcing of emissions from production (Jorgenson, 2009). Deforestation rates often increase in repressive nations, for whom it is relatively easy to enact the kinds of sweeping regulatory reforms-such as deregulation (or nonregulation) of land use-necessary to create a "good" business climate and attract foreign investment (Shandra, 2007).

Environmental load displacement allows developed nations to artificially reduce the full impact of their consumption levels by outsourcing production to developing nations. As a signifier that a nation is "open for business," I propose that business climate is acting as a pathway encouraging environmental load displacement, leading to increased emissions in developing nations. To explore this, in the analysis below I test the hypothesis that production-based anthropogenic $\mathrm{CO}_{2}$ emissions and business climate are positively associated in developing nations.

\section{Methods}

I estimate a time-series cross-sectional Prais-Winsten regression model with panelcorrected standard errors (PCSE), a correction for AR(1) disturbances, and twoway fixed effects to test my hypotheses. PCSE allow for disturbances that are heteroskedastic and contemporaneously correlated across panels, which corrects for understating the actual variability of coefficients. I have included country- and yearspecific intercepts to control for country- and year-specific effects, which corresponds to a two-way fixed-effects model. All of the variables are logged using log base 10 in order to correct for skewness and to allow the results to be interpreted as elasticity coefficients, where the coefficient for the independent variable is interpreted as the percentage change in the dependent variable associated with a $1 \%$ increase in the independent variable. 


\section{Data}

All data were collected from the World Bank, both from the World Development Indicators and Doing Business data sets, and span the period of 10 years from 2005 to 2014. I restricted my sample to developing nations by using data on national income level from the World Bank. I excluded those nations categorized as high-income; those with a 2016 gross national income per capita above $\$ 12,235$ in current US dollars (World Bank, 2017c). Studying developing nations is a common restriction for researchers when focusing on the impacts of the World Bank's activities, as most of the Bank's efforts are geared toward these nations (e.g., Grimes \& Kentor, 2003; Jorgenson, 2007, 2009; Shandra, 2007). The resulting sample includes 104 nations. All nations included in the sample are listed in Table 1.

Table 1: Nations in analysis.

\begin{tabular}{|l|l|l|l|}
\hline Afghanistan & Costa Rica & Lesotho & Senegal \\
\hline Albania & Dominican Rep. & Liberia & Serbia \\
\hline Argentina & Ecuador & Macedonia, FYR & Seychelles \\
\hline Armenia & Egypt, Arab Rep. & Malawi & Sierra Leone \\
\hline Azerbaijan & El Salvador & Malaysia & South Africa \\
\hline Bangladesh & Ethiopia & Mauritania & Sri Lanka \\
\hline Belarus & Fiji & Mauritius & Suriname \\
\hline Belize & Gabon & Mexico & Swaziland \\
\hline Benin & The Gambia & Moldova & Tajikistan \\
\hline Bhutan & Georgia & Mongolia & Tanzania \\
\hline Bolivia & Ghana & Montenegro & Thailand \\
\hline Bosnia \& Herzegovina & Guatemala & Morocco & Timor-Leste \\
\hline Botswana & Guinea & Mozambique & Togo \\
\hline Brazil & Guyana & Namibia & Tonga \\
\hline Bulgaria & Honduras & Nepal & Tunisia \\
\hline Burkina Faso & India & Nicaragua & Turkey \\
\hline Burundi & Indonesia & Nigeria & Uganda \\
\hline Cambodia & Iran, Islamic Rep. & Pakistan & Ukraine \\
\hline Cameroon & Jamaica & Palau & Uruguay \\
\hline Central African Republic & Jordan & Panama & Vanuatu \\
\hline Chad & Kazakhstan & Paraguay & Venezuela, RB \\
\hline Chile & Kenya & Peru & Vietnam \\
\hline China & Kyrgyz Rep. & Philippines & West Bank and Gaza \\
\hline Colombia & Lao, PDR & Romania & Yemen, Rep. \\
\hline Congo, Dem. Rep. & Latvia & Russian Federation & Zambia \\
\hline Congo, Rep. & Lebanon & Rwanda & Zimbabwe \\
\hline
\end{tabular}

Notes: PDR = People's Democratic Republic; FYR = Former Yugoslav Republic; RB = Bolivian Republic. Source: Author's selection of countries from Doing Business data set (World Bank, 2017b). 


\section{Independent variable}

My independent variable, "Distance to Frontier," is an index compiled by the World Bank in their data set Doing Business. The World Bank describes this variable as "scoring economies based on how business-friendly their regulatory systems are" (2017b). The variable name refers to the scale used: a score of 100 on a particular subscale represents the "frontier" (of the Distance to Frontier index), defined by the best performance by a country on that particular subscale since the start of data collection (World Bank, 2017b). The Distance to Frontier index is compiled using scores on 10 subscales: starting a business, dealing with construction permits, getting electricity, registering property, getting credit, protecting minority investors, paying taxes, trading across borders, enforcing contracts, and resolving insolvency. In order to assign scores, the World Bank surveys business owners and related experts in the largest city of each country included in the sample to ascertain the regulatory ease (or difficulty) of starting a business, focusing on the domestic and formal sectors (2017b). Other kinds of regulations that could impact businesses—such as environmental regulations_-were not included in the World Bank's measure.

While the World Bank focuses on regulations, these are not measured in terms of a lack or overabundance, but rather in terms of their perceived efficiency. The World Bank maintains that "rules" that enhance the protection of businesses as well as clarify and increase "the predictability of economic interactions" are essential to promoting economic activity (2017b, p. 13). Thus, the resulting Distance to Frontier index is designed to measure a distinctly pro-business regulatory climate, rather than equating a lack of regulatory oversight of the economy with pro-business policy. To this end, these data are gathered using surveys given to business experts in the largest city of each nation included in the sample. The surveys are constructed using case studies involving hypothetical businesses. For example, one of the measures used to compile the "starting a business" variable is how many days it would take to obtain the necessary permits to start a business (World Bank, 2017b).

The Doing Business data set was first released in 2005, but the World Bank did not begin creating a compiled score until 2010. In order for my analysis to cover the longest period possible, I created an indexed score based on the five subscales for which data are available starting in 2005: starting a business, registering property, getting credit, enforcing contracts, and resolving insolvency. To create my compiled Distance to Frontier score, I weighted each of the five subscales equally by dividing each score by 0.2 before adding them together. This resulted in a compiled score out of 100 for each of the 10 years. This score is highly correlated (0.912) with the World Bank's indexed score for 2010-17, and has a Cronbach's Alpha of 0.77, which is above the cutoff of 0.7 for indicating a good fit. The high correlation of 
the World Bank's index and my calculated index further suggests that the additional measures included in recent years have not substantively changed the overall business climate scores of each country. Because this increased time frame allows me to use longitudinal fixed-effects modeling techniques, this final indexed score for 2005-14 serves as the primary independent variable. The map in Figure 1 gives a general sense of which countries experienced the greatest change in their Distance to Frontier score over time. ${ }^{3}$

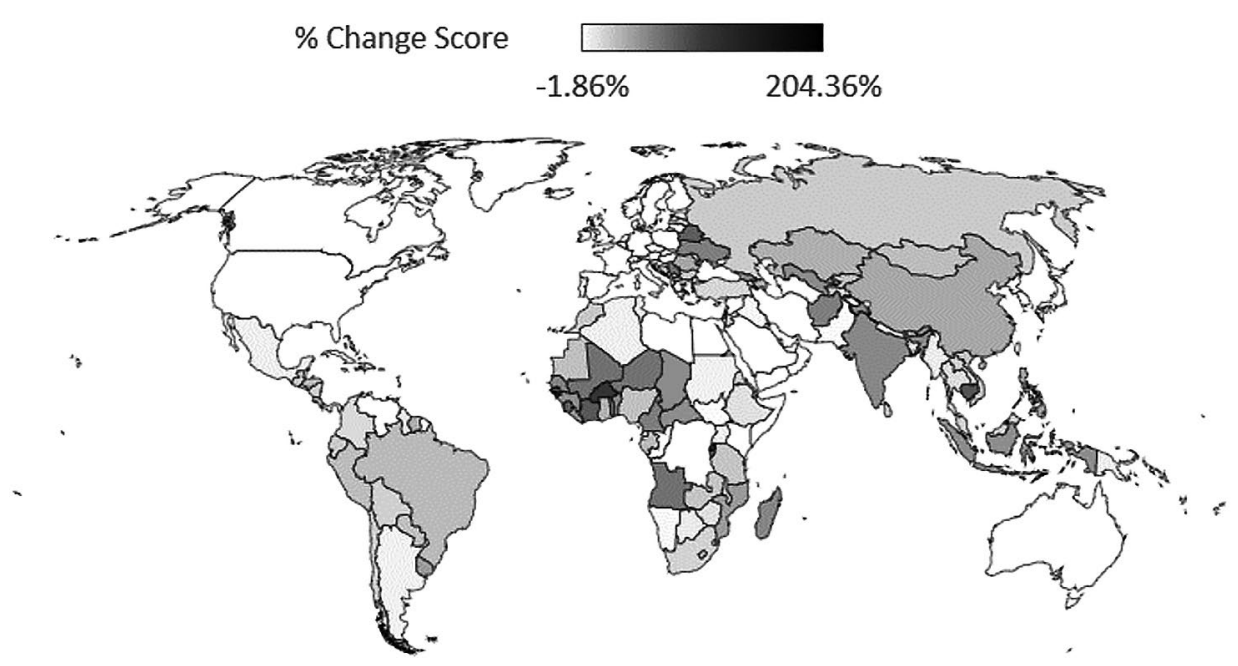

Figure 1: Distance to Frontier percent changes scores, 2005-14.

* all countries: countries without data are in white.

Source: Author's representation, derived from Doing Business data set (World Bank, 2017b).

Timor-Leste has the lowest Distance to Frontier score overall, but it is also the nation which experienced the greatest increase in its score over 10 years, with a $204 \%$ increase from a score of 6 to 18 . The average increase is $31 \%$, exemplified by Bosnia and Herzegovina, whose score was raised about 15 points over the 10 years, from 47 to 62 . While the majority of nations in the sample increased their scores over the decade in question, some nations experienced a decrease-although the changes were minimal. For example, Kenya's score dropped from 55 to 54, a $1.86 \%$ decrease.

3 A complete list of the Distance to Frontier and change scores for each of the 104 nations in the sample is available from the author upon request. 


\section{Dependent variable}

The dependent variable is total annual $\mathrm{CO}_{2}$ emissions from the burning of fossil fuels and the production of cement in kilotons, and was collected from the World Bank's World Development Indicators. The measure does not include $\mathrm{CO}_{2}$ emissions from land use changes and industrial processes other than those already mentioned (World Bank, 2017a). $\mathrm{CO}_{2}$ emissions are often used as a proxy for overall environmental emissions, as they are among the worst offenders in contributing to climate change because they account for the largest share of greenhouse gases (World Bank, 2017a). $\mathrm{CO}_{2}$ is also emitted as a byproduct of material production from a variety of economic sectors, making it a more comprehensive indicator of overall environmental impact than other types of emissions. Therefore, it is a popular choice for a dependent variable in cross-national studies of emissions (e.g., Grimes \& Kentor, 2003; Jorgenson et al., 2015; Jorgenson \& Clark, 2012; Longhofer \& Jorgenson, 2017; Huang, 2018). Additionally, $\mathrm{CO}_{2}$ emissions impact a global commons; the effects are not localized, as could be the case with other environmental indicators.

\section{Control variables}

The control variables include GDP per capita, manufacturing and exports as a percentage of GDP, population total, capital formation, and urban percentage of the population-all collected from the World Bank's Development Indicators data set, as well as foreign direct investment which was collected from the United Nations Conference on Trade and Development database (UNCTAD, 2017). GDP per capita is in constant 2010 US dollars and is used to control for economic development. Studies have shown that GDP has a strong positive association with $\mathrm{CO}_{2}$ emissions. Manufacturing (value added) as a percentage of GDP is used to control for differences in economic structure. Exports of goods and services as a percentage of GDP is included to control for integration into the international economy. Population growth has consistently been found to be an important driver of environmental stress. Foreign direct investment is measured in terms of inward stocks as a percentage of GDP and is used to control a well-researched pathway for environmental load displacement. Capital formation is measured as a percentage of GDP and is used to control for domestic investment. Finally, the urban percentage of the total population is used to control for urbanization. These variables are all standard controls used in cross-national research on environmental outcomes (e.g., Shandra, 2007; Jorgenson, 2007; Jorgenson \& Clark, 2012; Shandra et al., 2011; Huang, 2018). Table 2 provides descriptive statistics and correlations for all variables in the model. 
Table 2: Descriptive statistics and correlations.

\begin{tabular}{|c|c|c|c|c|c|c|c|c|c|c|}
\hline Variables & Mean & $\begin{array}{l}\text { Std. } \\
\text { Dev. }\end{array}$ & 1 & 2 & 3 & 4 & 5 & 6 & 7 & 8 \\
\hline 1. Population & 16.08 & 1.87 & 1 & - & - & - & - & - & - & - \\
\hline 2. GDP per capita & 7.79 & 1.09 & -0.16 & 1 & - & - & - & - & - & . \\
\hline 3. Urban population & 3.81 & 0.48 & -0.04 & 0.74 & 1 & - & - & - & - & - \\
\hline 4. Exports $\%$ of GDP & 3.47 & 0.53 & -0.33 & 0.42 & 0.36 & 1 & - & - & - & - \\
\hline $\begin{array}{l}\text { 5. Manufacturing \% } \\
\text { of GDP }\end{array}$ & 2.41 & 0.67 & 0.40 & 0.22 & 0.16 & 0.06 & 1 & - & - & - \\
\hline 6. Distance to Frontier & 3.91 & 0.30 & 0.02 & 0.55 & 0.33 & 0.31 & 0.31 & 1 & - & - \\
\hline 7. FDI stocks, inflows & 3.27 & 0.98 & -0.35 & 0.33 & 0.41 & 0.55 & -0.08 & 0.35 & 1 & - \\
\hline 8. Capital formation & 3.19 & 0.44 & -0.07 & 0.26 & 0.17 & 0.22 & 0.13 & 0.28 & 0.11 & 1 \\
\hline 9. $\mathrm{CO}_{2}(\mathrm{kt})$ & 9.25 & 2.28 & 0.77 & 0.44 & 0.42 & 0.02 & 0.52 & 0.38 & -0.07 & 0.12 \\
\hline
\end{tabular}

Notes: 977 observations. All variables have been logged. FDI = Foreign direct investment. Source: Author's summary.

\section{Results}

Table 3 reports the findings. The results of the analysis for the independent variable, Distance to Frontier, indicates that $\mathrm{CO}_{2}$ emissions and business regulation have a statistically significant $(\mathrm{p}<0.001)$ and positive relationship. For a $1 \%$ increase in a nation's Distance to Frontier score, there is a $0.151 \%$ increase in $\mathrm{CO}_{2}$ emissions, net of all other factors in the model. These results suggest that over the 10 years from 2005 to 2014, higher Distance to Frontier scores are associated with increasing $\mathrm{CO}_{2}$ emissions. The effects of population, GDP per capita, urbanization, and foreign direct investment are all positive and statistically significant, which is expected given the findings of previous research. However, the effects of exports, manufacturing, and capital formation are not statistically significant. Overall, the results support my hypothesis: $\mathrm{CO}_{2}$ emissions and business climate are positively correlated. ${ }^{4}$

4 Unreported analysis of high-income nations had null results: the results did not indicate a statistically significant relationship between business climate and $\mathrm{CO}_{2}$ emissions in high-income nations. 
Table 3: Elasticity coefficients for the regression of $\mathrm{CO}_{2}$ emissions, 2005-14: Prais-Winsten regression with panel-corrected standard errors (PCSE) and AR(1) correction.

\begin{tabular}{|l|c|}
\hline & $\begin{array}{c}\text { Model 1 } \\
\text { logged coefficient (PCSE) }\end{array}$ \\
\hline Distance to Frontier & $0.15(0.04)^{\star \star \star}$ \\
\hline Population & $1.97(0.15)^{\star \star \star}$ \\
\hline GDP per capita & $0.74(0.11)^{\star \star \star}$ \\
\hline Urbanization & $0.58(0.04)^{\star \star \star}$ \\
\hline Exports & $-0.02(0.03)$ \\
\hline Manufacturing & $-0.01(0.02)$ \\
\hline Foreign direct investment & $0.06(0.01)^{\star \star \star}$ \\
\hline Capital formation & $0.01(0.03)$ \\
\hline R-square & 0.996 \\
\hline $\mathrm{n}$ (observations) & 977 \\
\hline \# of nations & 103 \\
\hline Observations per nation (min/avg/max) & $3 / 9.5 / 10$ \\
\hline Rho & 0.412 \\
\hline
\end{tabular}

Note: * $p<0.05^{* \star} p<0.01{ }^{* \star *} p<0.001$. Variable names are italicized.

Source: Author's summary of analysis findings.

\section{Discussion and conclusion}

The simplified regulations promoted by the Doing Business version of "good business climate" (Dixit, 2009) have made it easier for many environmentally damaging industries to move to developing nations. Ecological unequal exchange theory emphasizes that this inequality is inherent in the relationship between developed and developing nations. The relationship between business climate and $\mathrm{CO}_{2}$ emissions in developing nations exists because environmentally damaging industries have mostly been outsourced from developed nations-thus resulting in the observed positive relationship between business climate and $\mathrm{CO}_{2}$ emissions in developing countries.

Low wages and cheap materials are two incentives for outsourcing (Grimes \& Kentor, 2003; Muradian et al., 2002), but business climate has added regulatory incentives as well. The 10 subscales $^{5}$ all focus on regulatory aspects of starting and running a business and those who rank well often have simplified processes

5 As a reminder: starting a business, dealing with construction permits, getting electricity, registering property, getting credit, protecting minority investors, paying taxes, trading across borders, enforcing contracts, and resolving insolvency. 
allowing for quick turnaround through a streamlined bureaucracy. Simplified and standardized business practices are the frontier against which the Doing Business data set is measuring nations. The ease of starting a business, however, also applies to the ease of outsourcing one. Additionally, it is possible that developing nations with "good" business climates also lack environmental regulations: this possible relationship merits further study.

World Bank data sets have international influence, often dictating norms and standards; whatever standard the World Bank uses to measure business climate is codified as "good" or "bad" business climate. This influence is seen in nations' responses to the rankings: leaders in nations such as Russia and India have made it a matter of economic policy to try and improve their nations' rankings (World Bank, 2017b). Measuring business climate is intended to measure economic progress by putting a spotlight on specific policies (Besley, 2015), but rather than creating an impartial variable, this measurement of business climate becomes part of an ideological debate itself. The World Bank has tried to greenwash its image after many critiques of its disregard for the environment (Babb, 2009), such as the relationship between its lending programs and multiple forms of ecological degradation (Shandra et al., 2011). However, there is little evidence that the World Bank has considered the environmental impacts of the regulations supported by its data sets; the Doing Business report does not mention the natural environment, though it does mention the inauguration or dissolution of environmental laws (often in the form of taxes) in a section detailing changes in business climate since the 2017 report.

Underlying the World Bank's construction of "ease of doing business" are assumptions about development that have potentially damaging repercussions for the environment. Ideally, economic growth could be accompanied by environmental protections and incentives for "green" innovation, but in reality it is often accompanied by carbon-intensive industrialization. Not only are developing nations the ones that are most encouraged to pursue economic growth as a path to development, but they are also the nations that usually experience the most harmful effects of environmental degradation, including climate change (Roberts \& Parks, 2007). This is especially problematic for the future development of these nations: the standard of living achieved by high-income nations has been subsidized by outsourcing ecologically harmful industries (Schor, 2015). 


\section{References}

Ambec, S., Cohen, M. A., Elgie, S., \& Lanoie, P. (2013). The Porter hypothesis at 20: Can environmental regulation enhance innovation and competitiveness? Review of Environmental Economics and Policy, 7, 2-22. doi.org/10.1093/reep/res016.

Babb, S. (2009). Behind the development banks. Chicago, IL: University of Chicago Press.

Babb, S., \& Chorev, N. (2016). International organizations: Loose and tight coupling in the development regime. Studies in Comparative and International Development, 51(1), 81-102. doi.org/10.1007/s12116-016-9217-7.

Beise, M., \& Rennings, K. (2005). Lead markets and regulation: A framework for analyzing the international diffusion of environmental innovations. Ecological Economics, 52, 5-17. doi.org/10.1016/j.ecolecon.2004.06.007.

Besley, T. (2015). Law, regulation, and the business climate: The nature and influence of the World Bank Doing Business project. Journal of Economic Perspectives, 29(3), 99-120. doi.org/10.1257/jep.29.3.99.

Bonds, E., \& Downey, L. (2012). "Green” technology and ecologically unequal exchange: The environmental and social consequences of ecological modernization in the world-system. Journal of World-Systems Research, 18(2), 167-186. doi.org/10.5195/jwsr. 2012.482 .

Broome, A., Homolar, A., \& Kranke, M. (2017). Bad science: International organizations and the indirect power of global benchmarking. European Journal of International Relations, 24(3), 1-26. doi.org/10.1177/1354066117719320.

Bunker, S. G. (1984). Modes of extraction, unequal exchange, and the progressive underdevelopment of an extreme periphery: The Brazilian Amazon, 1600-1980. American Journal of Sociology, 89(5), 1017-1064. doi.org/10.1086/227983.

Christmann, P., \& Taylor, G. (2001). Globalization and the environment: Determinants of firm self-regulation in China [Working Paper 01-15]. Virginia: Darden Graduate School of Business Administration, University of Virginia.

Dixit, A. (2009, January 4). Governance institutions and economic activity. Presidential address to the American Economic Association.

Djankov, S., McLiesh, C., \& Ramalho, R. (2006). Regulation and growth. Washington, DC: World Bank.

Frey, R. S. (1994). The international traffic in hazardous wastes. Journal of Environmental Systems, 23, 165-177.

Grimes, P., \& Kentor, J. (2003). Exporting the greenhouse: Foreign capital penetration and $\mathrm{CO}_{2}$ emissions 1980-1996. Journal of World-Systems Research, 9(2), 261-275. doi.org/ 10.5195/jwsr.2003.244. 
Hornborg, A. (2009). Zero-sum world: Challenges in conceptualizing environmental load displacement and ecologically unequal exchange in the world-system. International Journal of Comparative Sociology, 50(3-4), 236-262. doi.org/10.1177/0020715209105141.

Huang, X. (2018). Ecologically unequal exchange, recessions, and climate change: A longitudinal study. Social Science Research, 73, 1-12. doi.org/10.1016/j.ssresearch. 2018.03.003.

Jorgenson, A. K. (2004). Uneven processes and environmental degradation in the worldeconomy. Human Ecology Review, 11(2), 103-117.

Jorgenson, A. K. (2006). Unequal ecological exchange and environmental degradation: A theoretical proposition and cross-national study of deforestation, 1990-2000. Rural Sociology, 71(4), 685-712. doi.org/10.1526/003601106781262016.

Jorgenson, A. K. (2007). Does foreign investment harm the air we breathe and the water we drink? Organization \& Environment, 20(2), 137-156. doi.org/10.1177/ 1086026607302153.

Jorgenson, A. K. (2009). The transnational organization of production, the scale of degradation and ecoefficiency: A study of carbon dioxide emissions in less-developed countries. Human Ecology Review, 16(1), 64-74.

Jorgenson, A. K. (2016). The sociology of ecologically unequal exchange, foreign investment dependence and environmental load displacement: Summary of the literature and implications for sustainability. Journal of Political Ecology, 23, 328-491. doi.org/10.2458/ v23i1.20221.

Jorgenson, A. K., \& Clark, B. (2012). Are the economy and the environment decoupling? A comparative international study, 1960-2005. American Journal of Sociology, 118(1), 1-44. doi.org/10.1086/665990.

Jorgenson, A. K., Dick, C., \& Mahutga, M. C. (2007). Foreign investment dependence and the environment: An ecostructural approach. Social Problems, 54(3), 371-394. doi.org/ 10.1525/sp.2007.54.3.371.

Jorgenson, A. K., Schor, J., Huang, X., \& Fitzgerald, J. (2015). Income inequality and residential carbon emissions in the United States: A preliminary analysis. Human Ecology Review, 22, 93-105. doi.org/10.1086/665990.

Kentikelenis, A. E., Stubbs, T. H., \& King, L.P. (2016). IMF conditionality and development policy space, 1985-2014. Review of International Political Economy, 23(4), 543-582. doi.org/10.1086/665990.

Longhofer, W., \& Jorgenson, A. (2017). Decoupling reconsidered: Does world society integration influence the relationship between the environment and economic development? Social Science Research, 65, 17-29. doi.org/10.016/j.ssresearch.2017. 02.002 . 
Longhofer, W., Schofer, E., Miric, N., \& Frank, D. J. (2016). NGOs, INGOs, and environmental policy reform, 1970-2010. Social Forces, 94(4), 1743-1768. doi.org/ $10.1093 /$ sf/sow031.

McMichael, P. (2012). Development and social change: A global perspective. Thousand Oaks, CA: Sage Publications.

Muradian, R., \& Martinez-Alier, J. (2001). South-north materials flow: History and environmental repercussions. Innovation, 14(2), 171-187. doi.org/10.1080/135116101 20062344.

Muradian, R., O’Connor, M., \& Martinez-Alier, J. (2002). Embodied pollution in trade: Estimating the "environmental load displacement" of industrialized countries. Ecological Economics, 41, 51-67. doi.org/10.1080/13511610120062344.

Neumark, D., \& Muz, J. (2016). The "business climate" and economic inequality. Review of Income and Wealth, 62(1), 161-180. doi.org/10.1111/roiw.12146.

Rice, J. (2007). Ecological unequal exchange: International trade and uneven utilization of environmental space in the world system. Social Forces, 85(3), 1369-1392. doi.org/ 10.1353/sof.2007.0054.

Roberts, J. T., \& Parks, B. C. (2007). Fueling injustice: Globalization, ecologically unequal exchange and climate change. Globalizations, 4(2), 193-210. doi.org/10.1080/1474773 0701345218.

Rosa, E. A., Rudel, T. K., York, R., Jorgenson, A. K., \& Dietz, T. (2015). The human (anthropogenic) driving forces of global climate change. In R. E. Dunlap \& R. J. Brulle, Climate change and society: Sociological perspectives. American Sociological Association Task Force on Sociology and Global Climate Change. Oxford, UK: Oxford University Press. doi.org/10.1093/acprof:oso/9780199356102.003.0002.

Rudel, T. K., Roberts, J. T., \& Carmin, J. (2011). Political economy of the environment. Annual Review of Sociology, 37, 221-238. doi.org/10.1146/annurev.soc.012809.102639.

Schor, J. (2005). Prices and quantities: Unsustainable consumption and the global economy. Ecological Economics, 55, 309-320. doi.org/10.1146/annurev.soc.012809.102639.

Schor, J. (2015). Climate, inequality, and the need for reframing climate policy. Review of Radical Political Economics, 47(4), 525-536. doi.org/10.1177/0486613415576114.

Shandra, J. M. (2007). Economic dependency, repression, and deforestation: A quantitative, cross-national analysis. Sociological Inquiry, 77(4), 543-571. doi.org/10.1177/0486613 415576114.

Shandra, J. M., Shircliff, E., \& London, B. (2011). World Bank lending and deforestation: A cross-national analysis. International Sociology, 26(3), 292-314. doi.org/10.1177/ 0268580910392260.

Steinnes, D. N. (1984). Business climate, tax incentives, and regional economic development. Growth and Change, 15(2), 38-48. doi.org/10.1111/j.1468-2257.1984.tb00733.x. 
Tsalis, T. A., \& Nikolaou, I. E. (2017). Assessing the effects of climate change regulations on the business community: A system dynamic approach. Business Strategy and the Environment, 26, 826-843. doi.org/10.1002/bse.1953.

United Nations Conference on Trade and Development (UNCTAD). (2017). Foreign direct investment: Inward and outward flows and stock, annual. Geneva, CH: United Nations. Retrieved from unctadstat.unctad.org/wds/TableViewer/tableView.aspx?ReportId=96740.

World Bank. (2017a). Development indicators. Washington, DC: World Bank. Retrieved from: data.worldbank.org/indicator/EN.ATM.CO2E.KT.

World Bank. (2017b). Doing Business 2017: Equal opportunity for all. Washington, DC: World Bank. doi.org/10.1596/978-1-4648-0948-4_ov.

World Bank. (2017c, July 1). New country classifications by income level: 2017-2018 [Blog post]. The Data Blog. Retrieved from: blogs.worldbank.org/opendata/new-countryclassifications-income-level-2017-2018. 
This text is taken from Human Ecology Review, Volume 25, Number 1, 2019, published by ANU Press, The Australian National University, Canberra, Australia. doi.org/10.22459/HER.25.01.2019.04 